\section{Letter to the Editor}

Cite this article: Cole JB and Corcoran JN (2020) Yellow Oleander (Thevetia peruviana), a source of toxic cardiac glycosides, may be substituted for candlenuts (Aleurities moluccana) when taken as a weight-loss supplement. Cardiology in the Young $\mathbf{3 0}$ : 1755-1756. doi: 10.1017/S1047951120003480

Received: 5 September 2020 Accepted: 19 September 2020 First published online: 10 November 2020

\section{Address for correspondence:}

J. B. Cole, MD, Minnesota Poison Control System, 701 Park Ave, Mail Code: RL.240, Minneapolis, MN 55415, USA.

Tel: +1 612873 9347; Fax: +1 6129044289 . E-mail: jon.cole@hcmed.org

\title{
Yellow Oleander (Thevetia peruviana), a source of toxic cardiac glycosides, may be substituted for candlenuts (Aleurities moluccana) when taken as a weight-loss supplement
}

\section{Jon B. Cole ${ }^{1}(1)$ and Justin N. Corcoran ${ }^{2}$}

${ }^{1}$ Minnesota Poison Control System, Department of Emergency Medicine, Hennepin Healthcare and University of Minnesota Medical School, Minneapolis, MN, USA and ${ }^{2}$ Wisconsin Poison Center, Department of Emergency Medicine, Medical College of Wisconsin, Milwaukee, WI, USA

To the Editor,

We read with interest the case report by O'Brien et al., which describes an adolescent with cardiac glycoside-like poisoning after eating two purported candlenuts (Aleurites moluccana) for the purpose of weight loss. ${ }^{1}$ We are grateful to the authors for bringing attention to a potentially dangerous substance, purported to be a safe weight-loss supplement. We are concerned, however, with the conclusion that candlenuts may be responsible for digoxin-like toxicity. Candlenuts have never been definitively reported to contain cardiac glycosides. Further, this report shares similar features with a recent case of ours, where a substitution for cardiac glycoside-containing yellow oleander seeds was the culprit.

We cared for a 63-year-old woman who ate five seeds thought to be candlenuts, also for the purpose of weight loss. ${ }^{2}$ She presented 12 hours later with bradycardia ( 30 beats/minute), hyperkalaemia (serum potassium $7.3 \mathrm{mEq} / \mathrm{L}$ ), and an electrocardiogram demonstrated atrial fibrillation with a slow ventricular response, all consistent with cardiac glycoside poisoning. She suffered a fatal cardiac arrest before the clinical syndrome was fully recognised. As part of the post-mortem examination, seed samples and liver tissue were analysed and found to contain peruvoside confirming the seeds were in fact yellow oleander (Thevetia peruviana) and not candlenuts.

Both candlenuts and yellow oleander seeds are purported to facilitate weight loss. ${ }^{1,2}$ They bear a striking physical resemblance to one another; as remote as 2011 packages labelled as candlenuts have erroneously contained yellow oleander. ${ }^{3}$ Furthermore, they may both be referred to by the same common name (nuez de la India). Candlenuts contain saponins and phorbol esters, which typically cause only gastrointestinal symptoms such as vomiting and diarrhoea. Currently, there is no published evidence to suggest candlenuts contain cardiac glycosides, unlike yellow oleander which contains the cardiac glycosides thevetin and peruvoside. ${ }^{2}$ Given the clinical picture consistent with cardiac glycoside poisoning described by O'Brien et al., we are concerned this substitution may have occurred in their case.

Recognition of this substitution is clinically important, as patients meeting usual criteria for digoxin-specific fragment antigen-binding (Fab) antibodies, such as those with hyperkalaemia and unstable bradydysrhythmias, should likely receive antibodies. Furthermore, the dose needed to treat yellow oleander poisoning is likely substantially higher than most of the United States of America's clinicians are accustomed to. ${ }^{4} \mathrm{~A}$ randomised trial demonstrating the effectiveness of digoxin-Fab antibodies in yellow oleander poisoning used $1200 \mathrm{mg}$ ( 30 vials) after a dose-finding study. ${ }^{4}$ Administering such doses may be a logistical problem, as the cost of digoxin-Fab antibodies has risen substantially in the past decade (the average wholesale price of $\mathrm{DigiFab}^{\circ}$, the only preparation currently available in the United States of America is $\$ 4585 /$ vial); as such, hospitals frequently do not stock an adequate supply for this indication.

Because of this increasingly recognised substitution, we recommend similar patients receive digoxin-Fab antibodies in a timely manner based upon usual indications for acute digoxin poisoning. Clinicians and hospitals should also prepare to rapidly procure larger than usual doses. Furthermore, more invasive treatments, such as extracorporeal membrane oxygenation (ECMO) should be considered if profound shock or cardiac arrest develops (particularly if sufficient antibody doses are not immediately available), as ECMO has been successfully used to treat digoxin poisoning. ${ }^{5}$

Again, we thank O'Brien and colleagues for highlighting their important case, and encourage other clinicians who encounter patients purporting to have taken candlenuts with cardiac symptoms to consider yellow oleander poisoning in their differential diagnosis.

Acknowledgements. We thank Dr. Veena Singh (Midwest Medical Examiner's Office) for assistance with making the diagnosis on our patient with occult yellow oleander poisoning, and we thank the staff of the Minnesota 
Poison Control System who care for poisoned patients every day. Last, we wish to thank the family of our deceased patient, who were supportive of publishing our case so that an important public health message could be delivered.

Financial support. This research received no specific grant from any funding agency, commercial, or not-for-profit sectors.

Conflicts of interest. None.

\section{References}

1. O'Brien DR, Szymczuk V, Albaro CA. Weight loss supplement causing acute heart block in a child. Cardiol Young 2020; 30: 131-133.

2. Corcoran JN, Gray T, Bangh SA, Singh V, Cole JB. Fatal yellow oleander poisoning masquerading as benign candle nut ingestion taken for weight loss.
J Emerg Med 2020 Sep 8:S0736-4679(20)30708-3. doi: 10.1016/j.jemermed. 2020.07.026. Online ahead of print.

3. Lumsden Health Products Pty Ltd (also trading under Balanced Opinion Pty Ltd and LSM Pty Ltd) - The Latin Seed [Internet]. Australian Competition and Consumer Commission Product Safety Australia. 2011 [cited 2020 Sep 2]; Available from: https://www.productsafety.gov.au/recall/lumsdenhealth-products-pty-ltd-also-trading-under-balanced-opinion-pty-ltd-and-lsmpty-ltd-the-latin-seed

4. Eddleston M, Rajapakse S, Rajakanthan, et al. Anti-digoxin Fab fragments in cardiotoxicity induced by ingestion of yellow oleander: a randomised controlled trial. Lancet 2000; 355: 967-972.

5. Cole JB, Olives TD, Ulici A, et al. Extracorporeal membrane oxygenation for poisonings reported to U.S. Poison Centers from 2000 to 2018: an analysis of the national poison data system. Crit Care Med 2020; 48: 1111-1119. 